\title{
Personality Traits and Psychological Well-being among Youths of Rajkot District
}

\author{
Mohit M. Pandya ${ }_{1}$, Nitin R. Korat 2
}

\section{ABSTRACT:}

The purpose of present study was to find out correlation between the youths' Personality Traits and Psychological well-being. The said sample was 120 both males and females in equal numbers was selected through random sampling. Personality Traits Inventory \&Psychological well-being Inventory are tailor-made instruments, having sufficient reliability and validity. For the purpose of analysis, The Karl-Pearson ' $r$ ' technique was used. Present study reveals the result that there is significant positive correlation between the youths' Personality Traits and Psychological well-being. The authors suggest that there is a need to explore the rural and the urban youths' correlation in the line of above study.

Keywords: Personality Traits and Psychological well-being.

\section{INTRODUCTION}

However, there has been the different point of views on the dimensions and definitions of the Big Five (Goldberg, 1993). A well-accepted personality dimensions include Emotional Stability, Extraversion, and Openness to Experience, Agreeableness, and Conscientiousness (Costa \& McCrae, 1995; Goldberg, 1993; Judge et al., 2002; McCrae \& Costa, 1989; Saucier, 1994).According to Goldberg (1993), Emotional Stability (ES) refers to those who are selfreliant, stable, and adaptable to new situations. This concept sometimes is called Neuroticism (Emotional Instability). Extraversion(E) is defined as those who are sociable, gregarious, assertive, and cheerful. Openness to Experience $(\mathrm{O})$ refers to those who are curious, unconventional, and imaginative. Agreeableness (A) refers to those who have the tendency to be cooperative, generous, altruistic, and warm. Conscientiousness (C) is defined as those who are dependable, organized, persistent, and goal-oriented.

In short, thoughts, feelings, and behaviors that make a person different from another one is called "personality" (Levent, 2011:8). In this context, there are many research studies investigating personal characteristics that teachers should have, which illustrates the growing importance of personality traits.

${ }^{1}$ Ph.D. Research Scholar, Department of Psychology, Saurashtra University Rajkot- GujaratIndia 360005.

${ }^{2}$ Ph.D. Research Scholar, Department of Psychology, Saurashtra University Rajkot- GujaratIndia 360005.

(C) 2015, M Pandya, N Korat; licensee IJIP. This is an Open Access Research distributed under the terms of the Creative Commons Attribution License (http://creativecommons.org/licenses/by/2.0), which permits unrestricted use, distribution, and reproduction in any Medium, provided the original work is properly cited. 


\section{Personality Traits and Psychological Well-being among Youths of Rajkot District}

However, today, it is impossible to say that there is a consensus on the characteristics of an effective teacher (Çubukçu, 5zenbaş, Çetinbaş, Satı \& Şeker, 2012-28). Research studies examining personality are generally based on big five personality theory. According to big five personality theory there are five dimensions of personality which are (1) neuroticism, (2) extraversion, (3) openness, (4) agreeableness, (5) conscientiousness (Bacanl, İlhan, \&Aslan, 2009:262). In this research the big five personality theory is used as a framework in order to investigate the participants- personality.

"Well-being is a positive and sustainable condition that allows individuals, groups or nations to thrive and flourish" (Huppert, Baylis and Keverne 2005). "A state of complete physical mental and social well-being and does not consist only of the obsess of disease of infirmity" World health organization (WHO-1948). The fundamental proposition of Ryff's psychological well-being model was that subjective well-being (Diener, Lucas, \&Oishi, 2002). wasn't necessarily a condition for mental health (Robbins \& Kliewer, 2000). For example, a psychotic person might say being happy though psychologically distresses. Therefore, additional features are essential in evaluating psychological health (Robbins \& Kliewer, 2000).

The analysis of the factors associated with psychological well-being provides a means to understand precisely what it is. As Diener and Suh (2001) suggest, emotions are good predictors of psychological well-being. The purpose in this study was to examine the subjective perception that undergraduates have of psychological well-being on the basis of proposals from Ryff and Keyes (1995).

Psychological state of amputees is usually shattered, leading to a state of psychological un-wellness. Psychological well-being is a state of complete wellness in the mental status. Below the knee amputees experience a lot of negative feelings and expectations which are sometimes overt or covert. People with below the knee amputation experience anxiety and depression following amputation of the lower extremity, sometimes they experiences low self-esteem, loss of interest in life and can become suicidal. These psychological reactions correlate significantly with age and marital status, and there is no correlation with level of amputation, mode of ambulation and indication for amputation (Mosaku et al, 2009).

METHOD: Study method is presented below.

OBJECTIVES: To check correlation between Personality Traits and Psychological well-being of Rajkot District youths.

HYPOTHESIS: There is no correlation between Personality Traits and Psychological wellbeing of Rajkot district youths. 


\section{SAMPLE:}

The respondents of the present study 120 young people randomly selected from various Areas in Rajkot district. In present research the total sample consisted of 60 male and 60 female Rajkot district were chosen.

\section{TOOLS:}

\section{PERSONALITY TRAITS TEST}

The Big Five personality traits were operational zed as the pat- terns of people's behaviors. The International Personality Item Pool (IPIP) (Goldberg, 1999) was used to measure participant's behaviors. The scale reflects the five-factor model traits: Emotional Stability (Cronbach $\alpha=.71$ ); Extroversion (Cronbach $\alpha=.71$ ); Openness to Experience (Cronbach $\alpha=$ .70); Agreeableness (Cronbach $\alpha=.66$ ); and Conscientiousness (Cronbach $\alpha=.70$ ). Participants were asked to rate how accurately each statement described their behaviors. The scale contains 50 items with a 5-point scale ranging from Very Inaccurate (1) to Very Accurate (5). For example, the items are: "carry out my plans", "respect others", "do not like art", "make friend easily".

\section{PSYCHOLOGICAL WELL-BEING TEST}

It was developed by Bhogle and Prakash (1995), was used to measure Psychological well-being. The questionnaire contains 28 items with true and false response alternative. It covers 13 dimensions of psychological well-being. The maximum possible score is twenty eight and minimum is zero. High score indicates high level of psychological well-being. The test retest reliability coefficient is 0.72 and internal consistency coefficient is 0.84 . The author has reported satisfactory validity of the questionnaire.

\section{PROCEDURE:}

In this research two test were administrated individually as well as on young people, which collecting data for the study before attempting the questionnaire the subjects were requested to read the instruction carefully and follow them in true spirits. While the data collection was completed then ' $r$ ' was used to check correlations. 


\section{RESULTS AND DISCUSSION}

\section{Table-1}

Correlation calculation between Personality Traits and Psychological well-being of Rajkot district youths.

\begin{tabular}{|c|c|c|c|c|c|}
\hline Sr. no. & Variables & $\mathrm{N}$ & $\mathrm{df}$ & $\mathrm{r}$ & $\begin{array}{c}\text { Sig. } \\
\text { Levels }\end{array}$ \\
\hline 1. & $\begin{array}{c}\text { Personality } \\
\text { Traits }\end{array}$ & 120 & 118 & & \\
\hline 2. & $\begin{array}{c}\text { Psychological } \\
\text { well-being }\end{array}$ & 120 & 118 & 0.58 & 0.01 \\
\hline
\end{tabular}

We have seen the table no.1 the correlation between Personality Traits and Psychological well-being that ' $r$ ' value $=0.58$, so we can say that there was significant correlation between the respondents Personality Traits and Psychological well-being. Here, the positive $r$ value $=0.58$, which was significant at 0.01 levels.Hence, Hypothesis was rejected. It concluded that there was positive significance correlation between respondents Personality Traits and their Psychological well-being. It means that as Personality Traits increases the Psychological Well-being is Decreases.

\section{CONCLUSION}

The study presented in Rajkot district youths' Personality Traits and Psychological Wellbeing of which are connected to each other in check. Meaningful result was found. Variable moderately correlation was seen between the two. Thus, Youth Personality Traits and Psychological Well-being are correlated with each other moderately solid. Be the case. 


\section{REFERENCES}

1. Goldberg L. R. (1992) "The development of Markers for the Big-Five Factor structure."Psychological Assessment. 26-42

2.Goldberg, L. R. (1993). The Structure of Phenotypic Personality Traits. American Psychologist, 48, 26-34.

3. John, O. P., \&Srivastava, S. (1999). The Big-Five trait taxonomy: History, measurement, and theoretical perspectives. In L. A. Pervin\& O. P. John (Eds.), Handbook of personality: Theory and research (Vol. 2, pp. 102-138). New York: Guilford Press.

4. Jose M. Augusto LAndA, MAnueLPuLidoMArtos (2010) Emotionalintelligenceand personality traitsaspredictorsofpsychological well-being in Spanish undergraduates. Social behavior and personality, 38(6), 783-794@) Society for Personality Research (Inc.) DOI 10.2224/sbp.2010.38.6.783

5. Mehmet Kemal Aydın, BunyaminBavlı and BülentAlcı (2013). Examining the Effects of Preservice Teachers' Personality Traits on Their Teaching Competencies. International Online Journal of Educational Sciences ISSN: 1309-2707, 5 (3), 575-586

6. Nitin R. Korat, Gandharva R. Joshi (2014). Effects of Personal Variables of Call Centre Employees on their Psychological well-being. The International Journal of Indian Psychology: Volume: 01 | Issue: 04 No. 2 | ISSN 2348-5396

7. Ryff, C. D., Keyes, C. L. M. (1995). The structure of psychological well-being revisited. Journal of Personality and Social Psychology, 69(4), 719-727.

8. VikandaPornsakulvanich, NuchadaDumrongsiri (2012). An Analysis of Personality Traits and Learning Styles as Predictors of Academic Performance. ABAC Journal Vol. 32 No. 3 (September-December 2012, pp.1-19) 